\title{
HUBUNGAN KONSUMSI GARAM DAN TEKANAN DARAH PADA WANITA DI DESA BATUR JAWA TENGAH
}

\section{THE RELATIONSHP OF SALT CONSUMPTION AND BLOOD PRESSURE WOMEN IN THE VILLAGE OF BATUR CENTRAL JAVA}

\author{
Rosiana Eva Rayanti ${ }^{1 *}$, R. L. N. K.Retno Triandhini ${ }^{2}$, Debby Helda Sentia ${ }^{2}$ \\ ${ }^{* 1}$ Fakultas Kedokteran dan IImu Kesehatan, Universitas Kristen Satya Wacana, Jalan Kartini, Kota Salatiga, \\ Jawa Tengah, 50711, email: rosiana.saragih@staff.uksw.edu, Indonesia \\ ${ }^{2}$ Fakultas Kedokteran dan IImu Kesehatan, Universitas Kristen Satya Wacana, Jalan Kartini, Kota Salatiga, \\ Jawa Tengah, 50711, email: retno.triandhini@staff.uksw.edu, Indonesia \\ ${ }^{3}$ Fakultas Kedokteran dan IImu Kesehatan, Universitas Kristen Satya Wacana, Jalan Kartini, Kota Salatiga, \\ Jawa Tengah, 50711, email: sentiadebby@gmail.com, Indonesia
}

\begin{abstract}
Background: Excessive salt consumption is a factor that can contribute to the incidence of hypertension and trigger coronary heart disease and stroke

Objective: to determine the level of salt consumption, nutritional status, clinical examination, and the relationship between salt consumption and blood pressure in women in Batur Village

Method: Quantitative descriptive with design cross-sectional for 106 women aged 35-55 years. The research instrument is Recall 1x24 hours, Body Mass Index (BMI), Mid-Upper Arm Circumference (MUAC), waist-hip circumference ratio, blood pressure, uric acid test, Blood Sugar Level (BSL) and Fasting Glucose (FG).

Results: The average salt consumption of respondents is 4.5 grams'/day shows that it does not exceed the recommended limit of Regulation of Minister of Health No. 30 of 2013 ( 5 grams/day). The majority of BMI is level 1 obesity (39.6\%), MUAC (93\%) has a normal category. BMI and Waist-Hip Circumference Ratio (WHCR) $(65.1 \%)$ has a risk category. Blood pressure with the highest criteria (47\% systolic; $35 \%$ diastolic) has a pre-hypertensive category. Uric acid level, BSL and FG are normal. There is no significant relationship between salt consumption and systolic blood pressure $(p=0.373)$, and there is a significant relationship between salt consumption and diastolic blood pressure $(p=0.002 ; r=0.471)$

Conclusion: the salt consumption of respondents is normal below the recommended limit, the nutritional status of most respondents has a level 1 obesity category and there is a significant relationship between salt consumption and diastolic blood pressure in women in Batur Village
\end{abstract}

Keywords: Nutritional Status and Clinical Examination, Salt Consumption.

\section{PENDAHULUAN}

Penyakit tidak menular (PTM) yang termasuk di dalamnya penyakit jantung dan stroke adalah penyakit yang sering terjadi di masyarakat dan menyebabkan kematian dini utama pada abad ke-21. ${ }^{1}$ Mengonsumsi terlalu banyak garam dapat berkontribusi pada kejadian hipertensi dan memicu penyakit jantung koroner dan stroke. ${ }^{2}$

Berdasarkan perbandingan hasil data

Riset Kesehatan Dasar (Riskesdas) menunjukkan adanya peningkatan prevalensi
PTM dari tahun ke tahun. Berdasarkan prevalensi diabetes mellitus $1,1 \%$ tahun 2007, mencapai $2,1 \%$ tahun 2013. Prevalensi hipertensi berdasarkan hasil pengukuran terjadi penurunan sebesar $31,7 \%$ tahun 2007 menjadi $25,8 \%$ tahun 2013, namun terjadi peningkatan $34,1 \%$ pada tahun 2018, sedangkan hasil wawancara $7,6 \%$ tahun 2007 meningkat 9,5\% tahun 2013, namun terjadi penurunan $8,8 \%$ pada tahun 2018 . Demikian juga kecenderungan prevalensi obesitas pada perempuan dewasa $(\geq 15$ 
tahun) telah meningkat dari tahun ke tahun, $18,8 \%$ tahun 2007 , mencapai $26,6 \%$ tahun 2013, dan tahun 2018 meningkat menjadi $31 \% .^{2-4}$ Wanita sangat dipengaruhi oleh PTM, salah satu faktor yang berkontribusi ialah perubahan hormon dan kebiasaan makan yang buruk. Secara keseluruhan hasil PTM pada tahun 2013 di Indonesia, ${ }^{2}$ menunjukkan wanita lebih banyak mengalami peningkatan PTM dibandingkan dengan pria.

Perubahan gaya hidup dapat menyebabkan perubahan pola aktivitas. Kurangnya aktivitas fisik adalah salah satu faktor resiko terjadinya kegemukan. Kegemukan pada seseorang berhubungan dengan peningkatan tekanan darah, tejadinya penyakit kardiometabolik dan kematian akibat penyakit kardivaskular. ${ }^{5}$ Konsumsi makanan yang memicu timbulnya penyakit tidak menular diantaranya adalah konsumsi makanan yang banyak mengandung garam atau natrium, konsumsi makanan manis, dan konsumsi makanan berlemak. $^{6}$ Mengonsumsi makanan yang tidak sehat juga diketahui sangat berpengaruh terhadap status gizi seseorang. Hubungan antara asupan makanan dan status gizi menunjukkan bahwa asupan lemak, asupan energi dan asupan protein memiliki pengaruh signifikan terhadap kejadian obesitas. Selain itu, dapat memengaruhi status gizi diantaranya aktivitas fisik, gaya hidup dan status ekonomi. ${ }^{7}$

Berdasarkan data survei konsumsi makanan individu (SKMI) pada tahun 2014, menunjukkan rata-rata penduduk Indonesia mengonsumsi 3,6 gram garam. ${ }^{8}$ Di Provinsi Jawa, penduduk mengonsumsi 4 gram garam per orang per hari. $^{9}$ Hal ini menunjukkan konsumsi garam pada masyarakat mendekati batas rekomendasi yaitu 5 gram garam atau setara 1 sendok teh. $^{10}$

Data profil Kesehatan Kabupaten Semarang pada tahun 2014 menunjukkan terdapat distribusi penyakit diantaranya hipertensi esensial, hipertensi lain dan diabetes mellitus non-insulin. Pada tahun 2014 kejadian hipertensi esensial di Kabupaten Semarang mencapai 25,541 kasus, 9,330 kasus hipertensi dan 8,843 kasus diabetes mellitus non-insulin. Selama dua tahun terakhir, hipertensi tetap menjadi kasus PTM utama di Kabupaten Semarang. ${ }^{11}$

Tujuan dari penelitian ini adalah untuk mengetahui tingkat konsumsi garam, status gizi, pemeriksaan klinis dan hubungan antara konsumsi garam dengan tekanan darah pada wanita usia 35-55 tahun di Desa Batur, Kecamatan Getasan Jawa Tengah.

\section{BAHAN DAN CARA PENELITIAN}

Penelitian ini kuantitatif deskriptif dengan pendekatan cross-sectional. Teknik pengambilan sampel penelitan ini menggunakan random sampling, dalam penelitian ini didapatkan sampel 106 wanita dari jumlah populasi sebanyak 229 wanita. Desa Batur digunakan sebagai tempat penelitian dengan mempertimbangkan 
keberadaan tempat yang dapat diakses dan jumlah terbesar dari kasus PTM tertinggi menurut data profil Kesehatan Getasan 2014. Selain itu, penduduk Desa Batur mempunyai tradisi yang berbeda-beda dalam tingkat konsumsi garam. Penelitian dilakukan dari bulan Februari hingga April 2018.

Instrumen penelitian berdasarkan data identitas responden yang terdiri dari kuesioner data diri dan panduan wawancara, konsumsi makanan untuk konsumsi garam diperoleh dengan recall $1 \times 24$ jam selama satu kali pada hari libur (weekend day) dan dua kali hari kerja (working day), Semi Quantitative-Food Frequency (SQ-FFQ) didapat dari makanan yang sering dikonsumsi. Data Indeks Massa Tubuh (IMT) didapat melalui pengukuran berat badan dan tinggi badan, data Lingkar Lengan Atas (LiLA) didapat melalui pengukuran antara pangkal lengan atas dan ujung siku dan pengukuran Rasio Lingkar Pinggang Panggul (RLPP). Data tekanan darah didapat melalui pengukuran pada lengan dilakukan sebanyak tiga kali penggulangan. Data gula darah dilakukan dengan dua kali penggulangan yakni sewaktu dan puasa. Data asam urat dilakukan dengan 1 kali penggulangan. Pengukuran cek darah dan asam urat menggunakan alat Nesco.

Analisis data konsumsi garam dikonversikan menggunakan Daftar Komposisi Bahan Makanan (DKBM) sehingga jumlah gizi terlihat oleh model distribusi menggunakan Microsoft Excel yang dibandingkan dengan batas rekomendasi Permenkes No. 30 Tahun 2013.

\section{HASIL DAN PEMBAHASAN}

\section{Karakteristik Responden}

Tabel 1. Distribusi Responden Menurut Kelompok Umur, Pendidikan, Pekerjaan, Jenis Riwayat Penyakit dulu dan Riwayat Penyakit Keluarga

\begin{tabular}{ccc}
\hline Karakteristik & $\mathbf{N}=\mathbf{1 0 6}$ & $\mathbf{\%}$ \\
\hline \multicolumn{2}{c}{ Kelompok Umur } \\
\hline 35 tahun & 13 & 12,3 \\
\hline 36-45 tahun & 54 & 50,9 \\
\hline 46-55 tahun & 39 & 36,8 \\
\hline \multicolumn{2}{c}{ Pendidikan terakhir } \\
\hline Tidak Sekolah & 14 & 13,2 \\
\hline Tamat SD & 56 & 52,8 \\
\hline Tamat SMP & 25 & 23,6 \\
\hline Tamat SMA & 11 & 10,4 \\
\hline \multicolumn{3}{c}{ Pekerjaan } \\
\hline Petani & 95 & 89,6 \\
\hline IRT & 5 & 4,7 \\
\hline Pedagang & 3 & 2,8 \\
\hline Buruh & 3 & 2,8 \\
\hline
\end{tabular}

Riwayat Penyakit Sebelumnya

\begin{tabular}{ccc}
\hline Tidak ada & 79 & 74,5 \\
\hline Diabetes Mellitus & 0 & 0,0 \\
\hline Asam Urat & 11 & 10,4 \\
\hline Hipertensi & 16 & 15,1
\end{tabular}

Riwayat Penyakit Keluarga

\begin{tabular}{ccc}
\hline Tidak ada & 66 & 62,3 \\
\hline Diabetes Mellitus & 3 & 2,8 \\
\hline Asam Urat & 22 & 20,8 \\
\hline Hipertensi & 15 & 14,2 \\
\hline
\end{tabular}

Sumber: Data Primer, 2018

Berdasarkan data distribusi responden. Responden dikelompokkan menjadi tiga kelompok umur, yaitu 35 tahun (kelompok umur dewasa awal), 36-45 tahun (dewasa akhir) dan 46-55 tahun (lansia awal). Dari ketiga kelompok umur, yang paling banyak adalah umur 36-45 tahun, 
yaitu 54 orang $(50,9 \%)$. Dilihat dari tingkat pendidikan 56 orang $(52,8 \%)$ memiliki pendidikan tamat Sekolah Dasar. Hampir semua responden bekerja sebagai petani yaitu 95 orang $(89,6 \%)$. Berdasarkan data riwayat penyakit sebelumnya, menunjukkan sebanyak 79 orang $(74,5 \%)$ tidak mempunyai riwayat penyakit diabetes, asam urat dan hipertensi. Sedangkan pada riwayat penyakit keluarga, menunjukkan sebanyak 66 orang $(62,3 \%)$ tidak mempunyai riwayat penyakit diabetes, asam urat dan hipertensi.

\section{Konsumsi Garam}

Data rerata konsumsi garam menurut kelompok umur dapat dilihat pada tabel 2 , rerata konsumsi garam secara keseluruhan sebesar 4,5 gram per orang per hari. Konsumsi garam tertinggi pada kelompok umur 46-55 tahun yaitu 5 gram per orang per hari, dan terendah pada kelompok umur 35 tahun dengan 3,9 gram per orang per hari. Pada semua kelompok umur rerata konsumsi garam responden tidak melebihi batas normal yakni 5 gram per orang per hari yang dicantumkan dalam Permenkes No 30 tahun 2013.

Tabel 2. Rerata Konsumsi Garam (g/org/hari) berdasarkan Kelompok Umur

\begin{tabular}{ccc}
\hline \multirow{2}{*}{ Kategori } & \multicolumn{2}{c}{ Konsumsi Garam } \\
\cline { 2 - 3 } & Rerata \pm SD & Min-Max \\
\hline 35 tahun & $3,9 \pm 0,4$ & $3,1-5,6$ \\
\hline $36-45$ tahun & $4,7 \pm 0,2$ & $3-9,2$ \\
\hline $46-55$ tahun & $5 \pm 0,3$ & $3-8,3$ \\
\hline Total & $4,5 \pm 0,1$ & $3-9,2$ \\
\hline
\end{tabular}

Sumber: Data Primer, 2018

Garam ialah salah satu pengatur keseimbangan cairan bagi tubuh. Namun, konsumsi garam yang berlebihan akan berdampak bagi kesehatan. Semua responden ( $\mathrm{N}=106$ orang) wanita dalam penelitian ini mengonsumsi garam sebagai bumbu yang ditambahkan melalui proses pemasakan. Hal ini menunjukkan bahwa sebagian besar garam atau natrium yang dikonsumsi masyarakat berasal dari makanan olahan, dan penambahan garam pada saat memasak. ${ }^{5}$ Oleh karena itu, kekurangan asupan garam sangat jarang terjadi. Sebaliknya, kelebihan asupan garam sering menjadi penyebab munculnya berbagai macam penyakit yaitu penyakit jantung, hipertensi dan stroke. ${ }^{12-14}$ Pada penelitian ini diketahui responden yang paling banyak mengonsumsi garam yaitu usia 46-55 tahun, konsumsi garam akan semakin meningkat dengan bertambahnya usia dan akan mempengaruhi keadaan fisiologis lansia, bahwa semakin berkurangnya indera penciuman dan perasa pada lidah dapat berdampak pada kesehatan. $^{15} \mathrm{Hal}$ ini menunjukkan batasan konsumsi garam pada usia lanjut merupakan salah satu alternatif penanganan pada PTM. ${ }^{16}$

Berdasarkan hasil di atas, rata-rata responden mengonsumsi garam sebanyak 4,5 gram per orang per hari. Hasil ini masih dalam batas rekomendasi Permenkes Nomor 30 Tahun 2013 untuk konsumsi garam per orang per hari, setara dengan 5 gram (1 sendok teh).$^{10}$ Namun rerata nasional yakni 3,7 gram, $^{8}$ maka asupan garam oleh responden tergolong lebih tinggi. Hasil ini pun 
nasi, tahu, teh, minyak, gula pasir, gorengan dan garam. Semakin tinggi seseorang mengonsumsi sumber makanan maka sebagian besar akan menyebabkan masalah kesehatan seperti penyakit jantung, hipertensi, obesitas dan kolesterol tinggi.

\section{Food Recall}

Tabel 4. Distribusi Tingkat Asupan Gizi (Energi, Protein, Lemak, dan Karbohidrat)

\begin{tabular}{|c|c|c|c|c|}
\hline Variabel & Kategori & & $n$ & $\%$ \\
\hline \multirow{5}{*}{$\begin{array}{l}\text { Konsumsi } \\
\text { Energi }\end{array}$} & $\begin{array}{l}\text { Di atas } \\
\text { kebutuhan }\end{array}$ & $>120$ & 22 & 20,7 \\
\hline & Normal & $90-119$ & 38 & 35,8 \\
\hline & $\begin{array}{l}\text { Defisit } \\
\text { Ringan }\end{array}$ & $80-89$ & 11 & 10,3 \\
\hline & $\begin{array}{l}\text { Defisit } \\
\text { Sedang }\end{array}$ & $70-79$ & 13 & 12,2 \\
\hline & $\begin{array}{l}\text { Defisit } \\
\text { Berat }\end{array}$ & $<70$ & 22 & 20,7 \\
\hline \multirow{5}{*}{$\begin{array}{l}\text { Konsumsi } \\
\text { Protein }\end{array}$} & $\begin{array}{l}\text { Di atas } \\
\text { kebutuhan }\end{array}$ & $>120$ & 9 & 8,4 \\
\hline & Normal & $90-119$ & 14 & 13,2 \\
\hline & $\begin{array}{l}\text { Defisit } \\
\text { Ringan }\end{array}$ & $80-89$ & 14 & 13,2 \\
\hline & $\begin{array}{l}\text { Defisit } \\
\text { Sedang }\end{array}$ & $70-79$ & 18 & 16,9 \\
\hline & $\begin{array}{l}\text { Defisit } \\
\text { Berat }\end{array}$ & $<70$ & 51 & 48,1 \\
\hline \multirow{5}{*}{$\begin{array}{l}\text { Konsumsi } \\
\text { Lemak }\end{array}$} & $\begin{array}{l}\text { Di atas } \\
\text { kebutuhan }\end{array}$ & $>120$ & 57 & 53,7 \\
\hline & Normal & $90-119$ & 26 & 24,5 \\
\hline & $\begin{array}{l}\text { Defisit } \\
\text { Ringan }\end{array}$ & $80-89$ & 8 & 7,5 \\
\hline & $\begin{array}{l}\text { Defisit } \\
\text { Sedang }\end{array}$ & $70-79$ & 6 & 5,6 \\
\hline & $\begin{array}{l}\text { Defisit } \\
\text { Berat }\end{array}$ & $<70$ & 10 & 9,4 \\
\hline \multirow{5}{*}{$\begin{array}{l}\text { Konsumsi } \\
\mathrm{KH}\end{array}$} & $\begin{array}{l}\text { Di atas } \\
\text { kebutuhan }\end{array}$ & $>120$ & 106 & 100 \\
\hline & Normal & $90-119$ & 0 & 0 \\
\hline & $\begin{array}{l}\text { Defisit } \\
\text { Ringan }\end{array}$ & $80-89$ & 0 & 0 \\
\hline & $\begin{array}{l}\text { Defisit } \\
\text { Sedang }\end{array}$ & $70-79$ & 0 & 0 \\
\hline & $\begin{array}{l}\text { Defisit } \\
\text { Berat }\end{array}$ & $<70$ & 0 & 0 \\
\hline
\end{tabular}

Sumber: Data Primer, 2018

Data distribusi food recall dapat dilihat

pada tabel 4, sebanyak 38 orang mengkonsumsi energi memiliki kategori normal, sebanyak 51 orang mengonsumsi protein memiliki defisit berat, 57 orang mengonsumsi lemak dan seluruh responden (106) mengonsumsi karbohidrat dengan kategori di atas kebutuhan.

Berdasarkan hasil data distribusi asupan gizi responden dikategorikan menurut Departemen Kesehatan (Depkes) RI tahun 1996, menunjukkan konsumsi energi pada responden memiliki kategori normal, sedangkan asupan protein pada responden memiliki kategori defisit berat. Berdasarkan data distribusi makanan menunjukkan seluruh responden paling sering mengonsumsi makanan sumber protein nabati yaitu tahu, hal ini disebabkan tempat tinggal penduduk jauh dari perkotaan. Secara geografis, Desa Batur terletak di dataran tinggi dengan ketinggian 1200 meter diatas permukaan laut, rata-rata suhu udara yang dimiliki adalah $30^{\circ \mathrm{C}}$ dengan curah hujan sebesar $2500 \mathrm{~mm} / \mathrm{th}$. Faktor-faktor ini akan mempengaruhi pemilihan dan frekuensi makanan oleh responden. Asupan lemak dan asupan karbohidrat lebih tinggi dari yang dibutuhkan. Responden yang memiliki konsumsi lemak dan karbohidrat berlebihan cenderung menjadi gemuk. Berdasarkan data distirbusi IMT sebanyak 42 responden $(39,6 \%)$ mengalami obesitas dan diketahui bahwa bahan makanan tinggi lemak dan karbohidrat yang sering dikonsumsi dalam dua kali sampai tiga kali sehari yaitu nasi, minyak, gula pasir dan gorengan. Selain 
bahan makanan tinggi lemak dan karbohidrat, diketahui responden jarang mengonsumsi buah dan sayur. Buah yang dikonsumsi hanya jambu biji, dan sayuran yang dikonsumsi seperti wortel.

\section{Status Gizi}

Distribusi data antropometri dapat dilihat pada tabel 5. Dari data IMT menunjukkan, sebagian besar 43 orang $(40,6 \%)$ memiliki kategori obesitas tingkat 1 , sebagian besar 99 orang (93\%) LiLA responden memiliki kategori normal, dan hasil RLPP responden sebagian besar 69 orang $(65,1 \%)$ memiliki kategori beresiko tinggi.

Tabel 5. Distribusi Status Gizi (Indeks Massa

\begin{tabular}{llll}
\multicolumn{4}{c}{ Tubuh) } \\
\multicolumn{1}{c}{ Kategori } & $\mathbf{n = 1 0 6}$ & \% \\
\hline $\mathrm{IMT}\left(\mathrm{Kg} / \mathrm{m}^{2}\right)^{* *}$ & & & \\
Berat badan kurang & $<18.5$ & 1 & 0,9 \\
Berat badan normal & $18.5-22.9$ & 35 & 33,0 \\
Beresiko menjadi & $23-24.9$ & 17 & 16,0 \\
obesitas & & 42 & 39,6 \\
Obesitas tingkat 1 & $25.0-29.9$ & 11 & 10,4 \\
\hline Obesitas tingkat 2 & $\geq 30.0$ & 11
\end{tabular}

Sumber: Data Primer 2018

Indeks massa tubuh ialah salah satu untuk mengukur status gizi seseorang, terutama terkait kelebihan dan kekurangan berat badan. Penyebab terjadinya obesitas biasanya disebabkan oleh penumpukan lemak berlebih dalam tubuh, menyebabkan masalah kesehatan. Berdasarkan data distribusi di atas, $39,6 \%$ responden di kategorikan sebagai IMT obesitas tingkat 1. Jumlah IMT responden sangat dipengaruhi oleh beberapa hal, seperti asupan nutrisi dan pola makan. Semakin tinggi asupan nutrisi pada responden maka semakin tinggi kemungkinan seseorang mengalami peningkatan IMT. Tingginya kategori IMT obesitas tingkat 1 pada responden disebabkan gaya hidup mengonsumsi makanan atau minuman berlebih. Didapatkan makanan paling sering dikonsumsi oleh responden yaitu nasi, minyak kelapa dan gorengan dalam dua kali sampai tiga kali sehari. Hal ini akan meningkatkan obesitas pada tubuh yang menyebabkan resiko hipertensi, jantung, dan diabetes mellitus. ${ }^{20}$

Tabel. 6 Distribusi Lingkar Lengan Atas dan Rasio Lingkar Pinggang Panggul

\begin{tabular}{cccc}
\hline \multicolumn{1}{l}{ LILA } & & $\mathbf{n = 1 0 6}$ & $\%$ \\
\hline Normal & 23,5 & 99 & 93 \\
Tinggi & $>23,5$ & 7 & 7 \\
\hline RLPP & & \\
\hline Tidak Beresiko & $<0.8$ & 37 & 34,9 \\
Beresiko & $>0.8$ & 69 & 65,1 \\
\hline
\end{tabular}

Sumber: Data Primer, 2018

Penggukuran lingkar lengan atas (LiLA) digunakan sebagai indikasi adanya Kekurangan Energi Kronis (KEK) pada wanita hamil, tetapi dalam hasil penelitian ini tidak terdapat wanita hamil, dengan demikan, berdasarkan hasil analisis data diatas, 93\% responden memiliki kategori LiLA normal. Dari hasil distribusi rasio lingkar pinggang panggul (RLPP) diketahui sebanyak 61,5\% responden memiliki RLPP beresiko. Semakin tinggi RLPP, semakin tinggi resiko penyakit degeneratif. Timbunan lemak yang diukur dengan RLPP adalah faktor prediksi atau resiko tinggi penyakit jantung dan pembuluh darah. Hal ini dikarenakan pada wanita usia 
subur, lemak disimpan biasanya terjadi di beberapa daerah untuk melindungi organ reproduksi penting, sehingga wanita lebih besar memiliki RLPP beresiko. ${ }^{21}$

\section{Pemeriksaan Klinis dan Biokimia}

Tabel 7. Distribusi Pemeriksaan Klinis dan Biokimia

\begin{tabular}{|c|c|c|c|}
\hline Kategori & & $n=106$ & $\%$ \\
\hline \multicolumn{4}{|c|}{ Tekanan Darah Sistolik (mmHg) } \\
\hline Normal & $<120$ & 25 & 24 \\
\hline Prahipertensi & $120-139$ & 50 & 47 \\
\hline Hipertensi 1 & $140-159$ & 21 & 20 \\
\hline Hipertensi 2 & $>160$ & 10 & 9 \\
\hline \multicolumn{4}{|c|}{ Tekanan Darah Diastolik (mmHg) } \\
\hline Normal & $<80$ & 26 & 25 \\
\hline Prahipertensi & $80-89$ & 37 & 35 \\
\hline Hipertensi 1 & $90-99$ & 30 & 28 \\
\hline Hipertensi 2 & $>100$ & 13 & 12 \\
\hline \multicolumn{4}{|c|}{ Gula Darah Sewaktu (GDS) } \\
\hline Normal & $<140$ & 102 & 96 \\
\hline Pra-Diabetes Mellitus & $140-199$ & 2 & 2 \\
\hline Diabetes Mellitus & $\geq 200$ & 2 & 2 \\
\hline \multicolumn{4}{|c|}{ Gula Darah Puasa (GDP) } \\
\hline Normal & $<100$ & 96 & 91 \\
\hline Pra-Diabetes Mellitus & $100-125$ & 8 & 8 \\
\hline Diabetes Mellitus & $\geq 126$ & 2 & 2 \\
\hline \multicolumn{4}{|l|}{ Asam Urat } \\
\hline Normal & $\leq 6$ & 69 & 65 \\
\hline Tinggi & $>6$ & 37 & 35 \\
\hline
\end{tabular}

Sumber: Data Primer 2018

Hasil data pemeriksaan klinis dan biokimia dapat dilihat pada tabel 7. Dari data tekanan darah sistolik, menunjukkan 50 orang reponden $(47 \%)$ dalam kategori prahipertensi, sedangkan sebagian besar memliki kategori pra-hipertensi (35\%).

Berdasarkan data gula darah sewaktu, sebagian besar responden (102 orang) memiliki kategori normal, sedangkan gula darah puasa ada 96 orang $(91 \%)$ dalam kategori normal. Berdasarkan dari data asam urat, menunjukkan sebanyak 69 orang (65\%) dengan kategori normal.

Berdasarkan hasil penelitian tekanan darah sistolik dan diastolik pada responden rata-rata mempunyai kategori pra-hipertensi. Tingginya hasil tekanan darah pada responden disebabkan seseorang kurang memperhatikan kesehatan seperti pola makan, obesitas dan beberapa faktor lainnya seperti jenis kelamin dan faktor genetik (keturunan).

Pola makan seseorang ialah salah satu faktor pemicu hipertensi. Dari data distribusi makanan didapatkan responden sering mengonsumsi makanan sumber bumbu yaitu garam dalam dua kali sampai tiga kali sehari. Hal ini membuktikan bahwa pola makan responden yang menderita hipertensi sering mengonsumsi garam tinggi. Hal ini menyebabkan aliran darah ke ginjal berkurang. Apabila hal ini sering terjadi terus menurus, maka ginjal akan rusak dan tidak mampu berfungsi lagi. ${ }^{22}$ Dalam Pengurangan penggunaan garam akan sangat berdampak baik bagi penanggulangan hipertensi dimana penggunaan garam banyak digunakan pada saat memasak. ${ }^{23}$ Selain pola makan, obesitas adalah salah satu faktor resiko hipertensi. Dari data distribusi IMT responden memiliki kategori obesitas 1 dan makanan yang paling sering dikonsumsi responden dalam satu kali sehari yaitu gorengan. 
Jenis kelamin ialah faktor yang dapat mempengaruhi tekanan darah dan mempunyai faktor resiko yang tidak bisa diubah. ${ }^{24}$ Seluruh responden adalah wanita. Wanita sangat dipengaruhi oleh PTM, salah sau faktor yang berkontribusi ialah perubahan hormon. Peningkatan resiko tekanan darah tinggi seing terjadi setelah menopause. Di Indonesia wanita paling banyak menderita resiko tekanan darah tinggi dibandingkan dengan pria. $^{2}$ Hal ini disebabkan oleh perubahan hormon dan

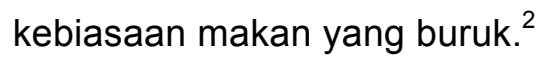

Riwayat penyakit (keturunan) ialah faktor keturunan. Sebagian responden $(14,2 \%)$ memiliki garis keturunan baik ayah atau ibu yang memiliki tekanan darah tinggi (hipertensi). Keluarga yang memiliki riwayat hipertensi atau penyakit jantung koroner dapat meningkatkan resiko hipertensi dua hingga lima kali lipat. Selain faktor genetik, faktor lingkungan juga dapat menyebabkan tekanan darah tinggi. Dalam penelitian Davidson, menyatakan bahwa jika orang tua keduanya hipertensi, 45\% akan turun ke anak-anaknya, tetapi jika orang tua salah satunya menderita hipertensi, 30\% akan turun ke anak-anaknya. ${ }^{25}$

Hasil penelitian pada gula darah sewaktu dan gula darah puasa menunjukkan sebagian besar responden memiliki kategori normal, sedangkan sebagian kecil responden memiliki gula darah tergolong tinggi. Tingginya peningkatan gula darah disebabkan karena terganggunya homeostatis dalam pengaturan gula darah. Hal ini juga sangat berkaitan dengan indeks massa tubuh responden. Selain IMT, pola makan juga sangat berpengaruh pada kadar gula darah. Dari data distribusi makanan didapatkan responden paling sering mengkonsumsi nasi dan gula dalam dua kali hingga tiga kali sehari. Peningkatan glukosa darah yang signifikan setelah makan makanan yang mengandung banyak karbohidrat atau gula. ${ }^{26}$

Hasil penelitian asam urat menunjukkan sebagian besar responden memiliki kategori normal, sedangkan sebagian kecil responden memiliki kategori tinggi. Peningkatan asam urat digambarkan sebagai hiperurisemia yang menyebabkan terjadinya gangguan ekskresi asam urat dari konsumsi tinggi purin. Dari data distribusi makanan didapatkan responden paling sering mengkonsumsi tahu yaitu dua kali sampai tiga kali sehari, tahu merupakan makanan yang mengandung purin. Beberapa keadaan yang dapat mempengaruhi proses ekskresi asam urat termasuk resistensi insulin.

\section{Hubungan Konsumsi Garam dengan Tekanan Darah}

Pada tabel 8 menunjukkan bahwa hasil uji statistik konsumsi garam dengan tekanan darah sistolik pada wanita di Desa Batur menggunakan uji Rank Spearman diperoleh nilai $p=0,373$ menunjukkan hasil bahwa $p<0,05$ tidak adanya hubungan yang signifikan antara kedua variabel. Rata-rata 
tekanan darah sistolik responden adalah $135 \pm 19,18 \mathrm{mmHg}$.

Tabel 8. Hubungan Konsumsi Garam dengan Tekanan Darah Sistolik

\begin{tabular}{|c|c|c|c|c|}
\hline \multirow[b]{2}{*}{ Variabel } & \multicolumn{4}{|c|}{ Konsumsi Garam } \\
\hline & $\begin{array}{c}\text { Rerata } \\
\pm \text { SD }\end{array}$ & $\begin{array}{l}\text { Min- } \\
\text { Max }\end{array}$ & $\begin{array}{c}P \\
\text { Value }\end{array}$ & $\mathbf{R}$ \\
\hline Normal & \multirow{3}{*}{$135 \pm 19$} & \multirow{3}{*}{$\begin{array}{l}101- \\
206\end{array}$} & \multirow{3}{*}{0,373} & \multirow{3}{*}{$\begin{array}{l}- \\
0,126\end{array}$} \\
\hline $\begin{array}{l}\text { Pra- } \\
\text { hipertensi }\end{array}$ & & & & \\
\hline $\begin{array}{l}\text { Hipertensi } 1 \\
\text { Hipertensi } 2 \\
\end{array}$ & & & & \\
\hline
\end{tabular}

Pada tabel 9 menunjukkan bahwa hasil uji statistik konsumsi garam dengan tekanan darah diastolik pada wanita di Desa Batur menggunakan uji Rank Spearman diperoleh nilai $p=0,002$ menunjukkan hasil bahwa $p<0,05$ yang mengindikasikan adanya hubungan yang signifikan antara kedua variabel. Rata-rata tekanan darah diastolik responden adalah $88 \pm 69 \mathrm{mmHg}$.

Tabel 9. Hubungan Konsumsi Garam dengan Tekanan Darah Diastolik

\begin{tabular}{|c|c|c|c|}
\hline \multirow[b]{2}{*}{ Variabel } & \multicolumn{3}{|c|}{ Konsumsi Garam } \\
\hline & $\begin{array}{c}\text { Rerata } \pm \\
\text { SD }\end{array}$ & $\begin{array}{l}\text { Min- } \\
\text { Max }\end{array}$ & $\begin{array}{c}P \\
\text { Value } \\
R\end{array}$ \\
\hline Normal & \multirow{4}{*}{$88 \pm 69$} & \multirow{4}{*}{$\begin{array}{l}66- \\
141\end{array}$} & \multirow{4}{*}{$\begin{array}{l}0,002 \\
0,47\end{array}$} \\
\hline Pra-hipertensi & & & \\
\hline Hipertensi 1 & & & \\
\hline Hipertensi 2 & & & \\
\hline
\end{tabular}

Asupan garam ialah salah satu asupan nutrisi yang dapat mempengaruhi tekanan darah dan timbulnya hipertensi. Hubungan asupan garam pada tekanan darah sistolik, tidak adanya hubungan yang signifikan antara kedua variabel. Sedangkan, adanya hubungan yang signifikan antara asupan garam dan tekanan darah diastolik $(p=0,002, r=0,471)$. Nilai koefisien korelasi sebesar 0,471 menunjukkan pengaruh korelasi positif berarti semakin tinggi orang mengonsumsi garam maka semakin pula tingkat hipertensi pada seseorang. Pada penelitian Wibowo menunjukkan bahwa terdapat hubungan antara asupan garam dengan kejadian hipertensi. $^{27}$ Konsumsi garam atau natrium yang berlebihan menyebabkan cairan dalam tubuh meningkat. Peningkatan tersebut mengakibatkan penyumbatan pada bagian diameter arteri yang menyebabkan jantung tidak dapat memompa darah sehingga menyebabkan tekanan darah tinggi atau hipertensi. Dalam penelitian Agustina mengatakan bahwa garam menyebabkan cairan menumpuk didalam tubuh karena cairan diluar sel menarik cairan agar tidak dikeluarkan sehingga meningkatkan volume dan tekanan darah. $^{25}$

\section{KESIMPULAN}

Berdasarkan penelitian yang telah dilakukan, dapat disimpulkan bahwa konsumsi garam pada responden tergolong normal dibawah batas rekomendasi Permenkes No 30 Tahun 2013. Status gizi responden tergolong obesitas. Tekanan darah tergolong pra-hipertensi. Adanya hubungan yang signifikan antara konsumsi garam dengan tekanan darah diastolik, dan tidak adanya hubungan signifkan antara konsumsi garam dengan tekanan darah sistolik. 


\section{TERIMA KASIH}

Kepala Puskesmas Getasan, Jl. Raya

Salatiga, Kopeng, Getasan, Ngelo,

Semarang, Jawa Tengah, 50774. Telp (0298)

318113.

\section{KEPUSTAKAAN}

1. Hendriyani $H$, Sulistyowati $E$, Noviardhi A. Konsumsi Makanan Tinggi Natrium, Kesukaan Rasa Asin, Berat Badan dan Tekanan Darah pada Anak Sekolah. Jurnal Gizi Klinik Indonesia. 2016;12(3):89-98.

2. Badan Penelitian dan Pengembangan Kesehatan. Riset Kesehatan Dasar (RISKESDAS) 2013. Lap Nas 2013. 2013;1-384.

3. Riset Kesehatan Dasar. Badan Penelitian dan pengembangan kesehatan Departemen Kesehatan,Republik Indonesia Desember 2008. 2007;

4. Kesehatan Badan Penelitian dan Pengembangan Kesehatan. Hasil Utama Riset Kesehatan Dasar. Kementrian Kesehat Republik Indonesia. 2018;1-200.

5. Hendriyani H, Pertiwi ED, Mintarsih SN. Perilaku Pemilihan Makanan Tinggi Natrium Berpengaruh Terhadap Asupan Natrium Penderita Hipertensi Di Kota Semarang. Gizi Indon. 2014;37(1):41-50.

6. Kementrian Kesehatan RI. Strategi Nasional Penerapan Pola Konsumsi Makanan dan Aktivitas Fisik untuk Mencegah Penyakit Tidak menular. 2011;

7. Simatupang MR. Pengaruh Pola Konsumsi, Aktivitas Fisik dan Keturunan Terhadap Kejadian Obesitas Pada Siswa Sekolah Dasar Swasta Di Kecamatan Medan Baru Kota Medan. Tesis pada Program Studi Adm dan Kebijak Kesehatan konsentrasi Adm Kesehatan komunitas/epidemiologi Univ Sumatera Utara. 2008;1-8.

8. Kementrian Kesehatan RI. Buku Studi Diet Total: Survei Konsumsi Makanan Individu Indonesia 2014. 2014. 210 p.

9. Sulistiowati E, dkk. Buku Studi Diet Total: Survei Konsumsi Makanan Individu Provinsi Jawa Tengah 2014. Studi Diet Total. 2014
10. Kementrian Kesehatan RI. Permenkes No. 30 Th 2013 gula garam lemak.pdf. 2013.

11. Dinas Kesehatan Semarang. Profil Kesehatan Kabupaten Semarang Tahun 2014. 2014;1-206.

12. Adriaansz PN, Rottie J, Lolong J. Hubungan Konsumsi Makanan dengan Kejadian Hipertensi pada Lansia di Puskesmasranomuut Kota Manado. ejournal Keperawatan (e-Kp). 2016;4(1)

13. Zuraida R. Faktor Risiko Pola Makan dan Hubungannya dengan Penyakit Jantung pada Pria dan Wanita Dewasa di Provinsi Lampung. Jurnal Kedokteran Universitas Lampung. 2015;5(9):18-22.

14. Fitriana R, Rohmawati N, Sulistiyani. Hubungan Antara Konsumsi Makanan dan Status Gizi dengan Kejadian Hipertensi pada Lansia (Studi di Posyandu Lansia Wilayah Kerja Puskesmas Wuluhan Kabupaten Jember). 2015;

15. Nirwansyah GA. Estimasi Asupan Garam Harian Pada Tingkat Individu Di Wilayah Jakarta Selatan. Institut Pertanian Bogor. 2017;

16. Haryanto J. The Effect of Coffe and Salt on Elderly Restriction with Hypertension. Jurnal Universitas Airlangga. 2017;

17. Witrianto. Tradisi Pola Makan Masyarakat Tradisional Minangkabau di Kubuang Tigobaleh. University Malaya. 2011;

18. Triandhini RLNKR, Rahardjo M, Putranti M. Sugar , Salt and Fat Consumption of Population in Batur Kidul Village Getasan Subdistrict Semarang Regency. Journal of Health. :1-11.

19. Bowring G, Beever WW. Charter of the royal college of surgeons. Prov Med Surg J. 1851;s1-15(14):387.

20. Prasetyani D. Analisis faktor yang mempengaruhi kejadian diabetes melitus (dm) tipe 2. J Kesehat Al Irsyad. 2011;2(24):1-9.

21. Harahap M. Gambaran Rasio Lingkar Pinggang Pinggul, Riwayat Penyakit dan Usia Pada Pegawai Polres Pekan Baru. Jurnal Kesehatan Masyarakat Andalas (JKMA). 2016;10(2):140-144

22. Anita DC. Status Nutrisi Pasien Gagal Ginjal Kronis dengan Diabetes Mellitus dan Non-Diabetes Mellitus. Media IImu 
Kesehatan. 2016;5(2):92-98.

23. Chen J, Tian Y, Liao Y, Yang S, Li Z, He $C$, et al. Salt-restriction-spoon improved the salt intake among residents in China. PLoS One. 2013;8(11):1-9.

24. Novita Sari et al. Asupan Serat Dan Tekanan Darah Wus Madura Penderita Tekanan Darah Tinggi Di Malang. Indones J Hum Nutr. 2016;1(2):135-48.

25. Agustina R, Raharjo BB. Faktor Risiko yang Berhubungan dengan Kejadian Hipertensi Usia Produktif (25-54 Tahun). Unnes Journal of Public Health. 2015;4(4):146-158.

26. Susanti S, Bistara DN. Hubungan Pola Makan Dengan Kadar Gula Darah Pada Penderita Diabetes Mellitus. Jurnal Kesehatan Vokasional. 2018;3(1):29.

27. Wibowo DP, Istianah U, Adinugraha TS. Faktor-faktor yang Berhubungan dengan Kejadian Hipertensi di Puskesmas Kalibawang Kulon Progo. Media IImu Kesehatan. 2015;4(2):135-41. 